\title{
A Huge Diversity of Metopids (Ciliophora, Armophorea) in Soil from the Murray River Floodplain, Australia. II. Morphology and Morphogenesis of Lepidometopus platycephalus nov. gen., nov. spec.
}

\author{
Peter VĎAČNÝ' ${ }^{1}$, Wilhelm FOISSNER ${ }^{2}$ \\ ${ }^{1}$ Comenius University in Bratislava, Department of Zoology, Bratislava, Slovakia; ${ }^{2}$ Salzburg University, FB Ecology and Evolution, \\ Salzburg, Austria
}

\begin{abstract}
The morphology and morphogenesis of a new Australian metopid ciliate, Lepidometopus platycephalus nov. gen., nov. spec., were studied using live observation, various silver impregnation methods, scanning electron microscopy, and morphometry. The new genus is outstanding in having epicortical scales (lepidosomes) and a strongly flattened and distinctly projecting preoral dome. Diagnostic features of $L$. platycephalus include a small, reniform body carrying an elongated caudal cilium, about 11 ciliary rows, and an adoral zone composed of an average of 11 polykinetids. The morphogenesis of L. platycephalus matches data from other metopids in that (1) the body is drastically re-shaped, (2) the parental oral structures are reorganized but do not contribute to the daughter oral ciliature, (3) the opisthe's adoral polykinetids originate pleurotelokinetally, (4) the opisthe's paroral membrane is formed via re-arrangement of the posterior portion of the first two perizonal rows, and (5) the opisthe's perizonal stripe is made by three parental perizonal rows and two dorsolateral ciliary rows. The morphogenetic data corroborate phylogenetic analyses in that caenomorphids are only superficially similar to metopids; metopids and clevelandellids are closely related; and litostomateans are the best candidates for a sister group of the metopid-clevelandellid assemblage within the SAL superclade.
\end{abstract}

Key words: Binary fission, lepidosomes, Metopidae, morphometry, stomatogenesis

\section{INTRODUCTION}

The order Metopida Jankowski, 1980 unites freeliving armophoreans with more or less distinct anterior body torsion and a preoral dome carrying a densely ciliated perizonal stripe (Jankowski 2007, Lynn 2008). These elegant ciliates graze bacteria in anoxic or mi-

Address for correspondence: Peter Vd'ačný, Department of Zoology, Faculty of Natural Sciences, Comenius University in Bratislava, Ilkovičova 6, 84215 Bratislava, Slovak Republic; E-mail: vdacny@ fns.uniba.sk croaerophilic environments with the aid of an obliquely extending or spiralled adoral zone of polykinetids and a tongue-like paroral membrane (Foissner et al. 1992, 2002; Esteban et al. 1995; Foissner 1998). In spite of the wide distribution and ecological significance in oxygen-depleted environments (Saccà 2012, Hu 2014, Foissner 2016a, Tirjaková et al. 2016), taxonomical and morphological research on metopids has been revived only recently (e.g., Bourland and Wendell 2014; Bourland et al. 2014, 2017; da Silva-Neto et al. 2015; Foissner 2016b, c; Omar et al. 2017; Vd'ačný and Foissner 2017). 
Australia has a comparatively huge, undescribed diversity of metopids, several of which have a peculiar morphology (Foissner 2016b, c; Vd'ačný and Foissner 2017). For instance, Heterometopus meisterfeldi Foissner, 2016c, discovered in soil from the Fogg Dam in the Northern Territory, is outstanding in having a J-shaped adoral zone that extends slightly obliquely over the ventral side. Thus, the oral apparatus of Heterometopus is more similar to that of Blepharisma Perty, 1849 or Pseudoblepharisma Kahl, 1927 than to that of metopids. The floodplain of the Murray River in Southeast Australia also houses several remarkable species, such as Metopus murrayensis and the large M. magnus and M. rex (Vd'ačný and Foissner 2017). Metopus magnus has a lenticular macronucleus with a small concavity for the micronucleus while $M$. murrayensis exhibits a globular macronucleus surrounded by a cloud of highly refractive granules. Moreover, its oral area is unique in that the preoral dome is conspicuously thick, the dome lip is very broad, and the side stripe forms a flat channel with prominent ribs.

In this paper, we describe another remarkable Australian metopid, viz., Lepidometopus platycephalus nov. gen., nov. spec., from floodplain soil of the Murray River. Its body lost the typical metopid shape and is covered with epicortical scales, as in trachelophyllids of the litostomatean order Spathidiida (Nicholls and Lynn 1984; Foissner et al. 2002; Foissner 2005a, 2016b). The morphogenesis of $L$. platycephalus shows that the main ontogenetic events of metopids are more similar to those of litostomateans than to those of spirotricheans. Moreover, comparative analyses of morphogenetic data demonstrate that the metopid-clevelandellid kinship is rather well underpinned while a close relationship of metopids and caenomorphids is unlikely.

\section{MATERIALS AND METHODS}

\section{Sampling and sample processing}

Lepidometopus platycephalus nov. gen., nov. spec. was isolated from the upper $5 \mathrm{~cm}$ soil layer of the floodplain of the Murray River at the Landside of Ryans road near to the town of Albury, Southeast Australia (S36 $\left.06^{\prime} \mathrm{E} 146^{\circ} 54^{\prime}\right)$. The material was collected in February 2006, air-dried for three weeks, and sealed in a plastic bag. The ciliates were reactivated from resting cysts in summer 2006, using the non-flooded Petri dish method, as described in Vd'ačný and Foissner (2012). A more detailed description of the sample is provided by Vd'ačný and Foissner (2017).

\section{Taxonomic methods}

Lepidometopus platycephalus was studied using a combination of in vivo observation, silver impregnation, and scanning electron microscopy (SEM), as described by Foissner (1991, 2014). Live ciliates were studied at low and high magnifications with bright field and differential interference contrast. The ciliature was revealed with protargol and silver carbonate impregnation. The ontogenetic processes were reconstructed from protargol preparations, which show concomitantly body shape, ciliary pattern, and nuclear apparatus. In vivo measurements were performed at 40-1000 $\times$ while counts and measurements on protargol-impregnated specimens were conducted at a magnification of $1000 \times$. Illustrations of live specimens were based on free-hand sketches and photographs while those of impregnated cells were made with a drawing device.

\section{Terminology}

General terminology follows Lynn (2008). Interphase terminology is based on Kahl (1932), Jankowski (1964a), Foissner and Agatha (1999), and Foissner (2016c). The oral patterns were classified into types by Vd'ačný and Foissner (2017). Lepidometopus platycephalus represents a fourth type characterized as follows (Fig. 1): The distal portion of the preoral dome is strongly flattened and projects distinctly in lateral view, forming a right or nearly right angle with the main body axis. The dome lip is inconspicuous. The side stripe forms a moderately deep channel. The adoral zone extends vertically to strongly obliquely over the anterior half of the ventral side. This type occurs in Lepidometopus nov. gen. and possibly also in two insufficiently known genera, Palmarella Jankowski, 1975 and Tesnospira Jankowski, 1964b.

Ontogenetic terminology is according to Foissner (1996). Division stages are distinguished as follows: Early dividers are characterized by the proliferation of basal bodies in the dorsal, dorsolateral and postoral kineties; the macronucleus is in the anterior body half. Mid-dividers have assembled the adoral zone of polykinetids both in proter and opisthe; the macronucleus is in the cell centre. Late dividers are constricted in the middle; the macronucleus is dumbbell-shaped.

\section{RESULTS}

\section{Lepidometopus nov. gen. Vd'ačný and Foissner}

Diagnosis: More or less reniform Metopidae with epicortical scales. Five perizonal kineties. Type 4 oral area.

Type species: Lepidometopus platycephalus nov. spec.

Etymology: A composite of the stem of the Latin adjective lepid·us, $-a,-u m[\mathrm{~m}, \mathrm{f}, \mathrm{n}]$ (charming), the thematic vowel'o-, and the genus-group name Metopus. Masculine gender. 
Lepidometopus platycephalus nov. spec. Foissner and Vd'ačný

Diagnosis: Size about $45 \times 20 \mu \mathrm{m}$ in vivo. Body broadly to narrowly reniform with a somewhat rhomboid appearance when viewed ventro- or dorsolaterally. Macronucleus between anterior and posterior end of adoral zone, globular to oblong; one globular to broadly ellipsoid micronucleus. Contractile vacuole terminal. Epicortical scales about $1.25 \times 0.45 \mu \mathrm{m}$ in SEM, flat with margin curled up. On average 11 ciliary rows; caudal cilium about $20 \mu \mathrm{m}$ long. Perizonal stripe composed of five kineties extending approximately $46 \%$ of body length and forming about 19 false kineties. Adoral zone extends about $50 \%$ of body length, composed of an average of 11 polykinetids.

Type locality: Loamy soil and leaf litter from the floodplain of the Murray River near to the town of A1bury, Australia (S36 06' E146 $54^{\prime}$ ).

Type material: The holotype slide and eight paratype slides with protargol-impregnated specimens have been deposited in the Museum of Natural History (Biologiezentrum) in Linz (LI), Austria. The holotype (Fig. 2K, L) and relevant paratype specimens as well as dividers have been marked by black ink circles on the coverslip.

Etymology: Derived from the Ancient Greek adjective platús ( $\pi \lambda \alpha \tau \dot{s} \varsigma$, flat) and the Ancient Greek noun képhalos ( $\kappa \dot{\varepsilon} \varphi \breve{\alpha} \lambda o \varsigma[\mathrm{m}]$, head), referring to the strongly flattened preoral dome. The composite name is latinized and treated as a noun in the nominative singular standing in apposition to the generic name [Art. 11.9.1.2 of the International Commission on Zoological Nomenclature (1999)]

Description: Size in vivo 35-50 × 15-30 $\mu \mathrm{m}$, usually about $45 \times 20 \mu \mathrm{m}$, as calculated from some in vivo measurements and the morphometric data adding $15 \%$ preparation shrinkage (Table 1). Body asymmetric and thus multi-shaped: broadly to narrowly reniform in ventro- and dorsolateral views (Figs $2 \mathrm{~A}, \mathrm{G}, \mathrm{K}-\mathrm{V}, 3 \mathrm{~A}, \mathrm{~B}$, $4 \mathrm{C}, \mathrm{D}$ ), broadly crescentic in lateral views (Figs $2 \mathrm{~F}, \mathrm{H}$, $4 \mathrm{~B}, \mathrm{E}, 5 \mathrm{~B})$, and dumbbell-shaped in ventrocaudal views

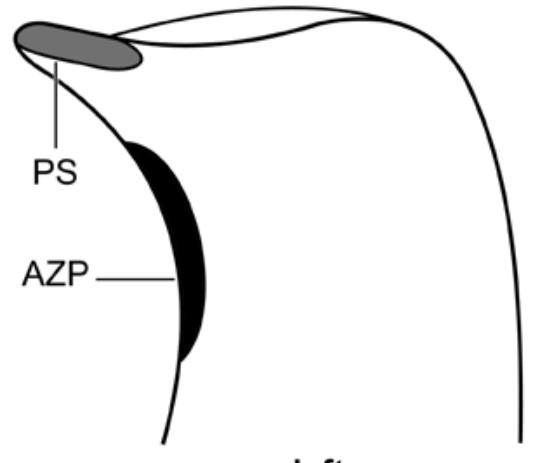

left

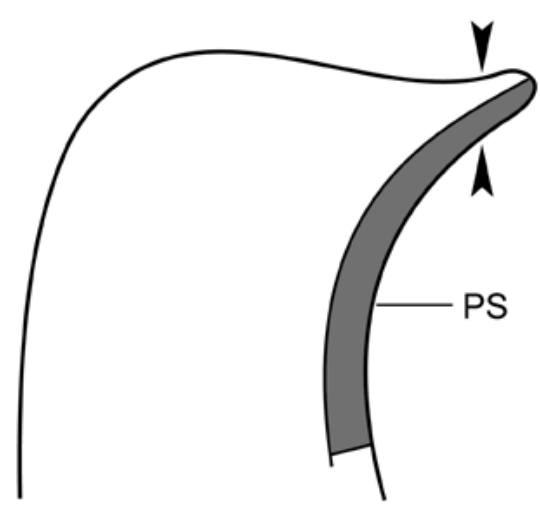

right

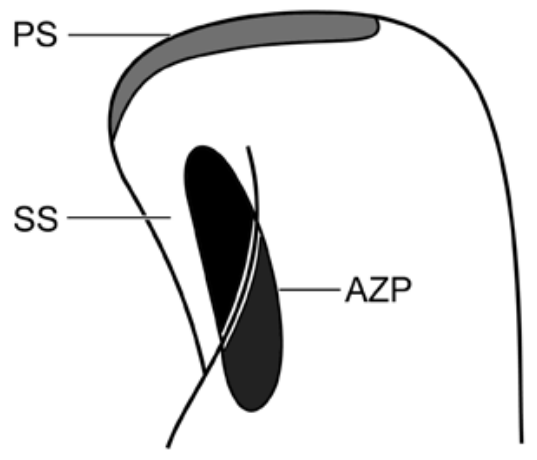

ventrolateral

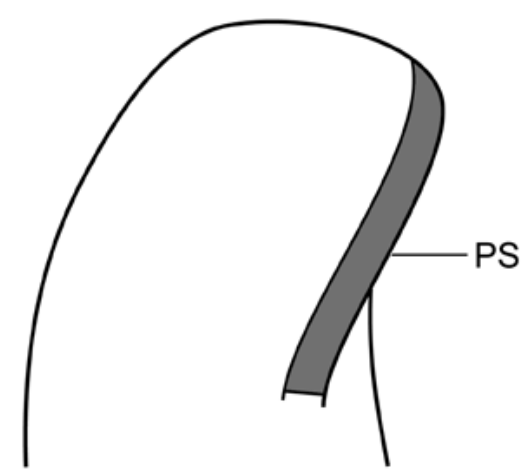

dorsolateral

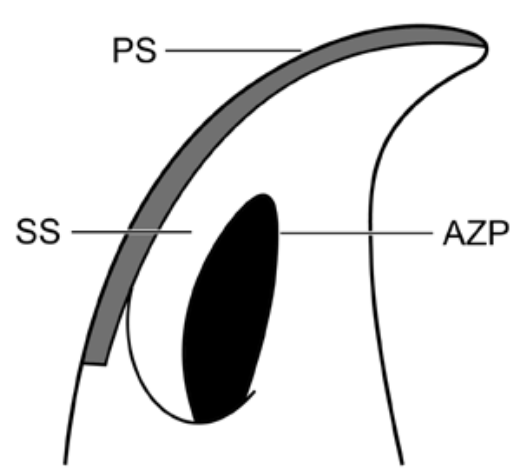

ventral

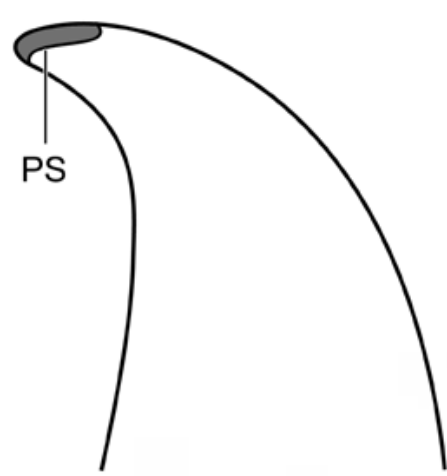

dorsal

Fig. 1. Various views of semi-schematized anterior body portion of Lepidometopus. Opposed arrowheads mark the strongly flattened distal portion of the preoral dome. AZP - adoral zone of polykinetids (black); PS - perizonal stripe (grey); SS - side stripe. 
Table 1. Morphometric data on Lepidometopus platycephalus nov. gen., nov. spec.

\begin{tabular}{|c|c|c|c|c|c|c|c|c|}
\hline Characteristics $^{\mathrm{a}}$ & Mean & M & $\mathrm{SD}$ & SE & $\mathrm{CV}$ & Min & Max & $n$ \\
\hline Body, length & 37.2 & 38.0 & 3.7 & 0.8 & 10.0 & 31.0 & 44.0 & 21 \\
\hline Body, maximum width of preoral dome & 19.7 & 20.0 & 2.6 & 0.6 & 13.2 & 14.0 & 24.0 & 21 \\
\hline Body, width at cytostome & 17.3 & 17.0 & 2.0 & 0.4 & 11.6 & 14.0 & 21.0 & 21 \\
\hline Body, maximum postoral width & 22.0 & 22.0 & 3.5 & 0.8 & 16.0 & 15.0 & 28.0 & 21 \\
\hline Body, length:width ratio & 1.8 & 1.7 & 0.3 & 0.1 & 17.7 & 1.4 & 2.8 & 29 \\
\hline Anterior body end to proximal end of PS, distance & 17.1 & 17.0 & 2.5 & 0.5 & 14.4 & 12.0 & 21.0 & 21 \\
\hline Perizonal stripe, percentage of body length & 46.1 & 47.4 & 5.9 & 1.3 & 12.7 & 34.1 & 58.3 & 21 \\
\hline Anterior body end to distal end of AZP, distance & 6.3 & 6.0 & 1.0 & 0.2 & 15.1 & 5.0 & 8.0 & 21 \\
\hline Anterior body end to proximal end of AZP, distance & 18.7 & 19.0 & 1.7 & 0.4 & 9.0 & 15.0 & 21.0 & 21 \\
\hline Adoral zone of polykinetids, percentage of body length & 50.3 & 50.0 & 3.4 & 0.7 & 6.8 & 45.7 & 58.8 & 21 \\
\hline Anterior body end to distal end of PM, distance & 9.9 & 10.0 & 1.6 & 0.4 & 15.8 & 7.0 & 13.0 & 19 \\
\hline Anterior body end to macronucleus, distance & 6.5 & 5.5 & 2.8 & 0.6 & 42.6 & 3.0 & 15.0 & 21 \\
\hline Macronucleus, length & 12.4 & 12.0 & 2.6 & 0.6 & 21.4 & 8.5 & 20.0 & 21 \\
\hline Macronucleus, width & 7.1 & 7.0 & 1.4 & 0.3 & 20.1 & 4.0 & 9.0 & 21 \\
\hline Macronucleus, length:width ratio & 1.9 & 1.6 & 0.9 & 0.2 & 48.1 & 1.0 & 5.0 & 21 \\
\hline Macronucleus, number & 1.0 & 1.0 & 0.0 & 0.0 & 0.0 & 1.0 & 1.0 & 21 \\
\hline Micronucleus, largest diameter & 2.5 & 2.5 & - & - & - & 2.0 & 3.0 & 21 \\
\hline Micronucleus, number & 1.0 & 1.0 & 0.0 & 0.0 & 0.0 & 1.0 & 1.0 & 21 \\
\hline Somatic ciliary rows, total number & 11.1 & 11.0 & 1.1 & 0.2 & 10.1 & 9.0 & 13.0 & 23 \\
\hline Perizonal ciliary rows, number & 5.0 & 5.0 & 0.0 & 0.0 & 0.0 & 5.0 & 5.0 & 21 \\
\hline False kineties in perizonal stripe, number & 18.7 & 19.0 & 2.5 & 0.5 & 13.1 & 15.0 & 23.0 & 21 \\
\hline Adoral polykinetids, number & 11.0 & 11.0 & 0.9 & 0.2 & 7.8 & 10.0 & 12.0 & 23 \\
\hline Paroral membrane, length & 10.3 & 10.0 & 1.1 & 0.2 & 10.2 & 9.0 & 13.0 & 19 \\
\hline
\end{tabular}

${ }^{a}$ Data based on mounted, protargol-impregnated, and randomly selected specimens from a non-flooded Petri dish culture. Measurements in $\mu \mathrm{m}$. AZP - adoral zone of polykinetids; CV - coefficient of variation (\%); M - median; Max - maximum; Mean - arithmetic mean; Min - minimum; PM - paroral membrane; PS - perizonal stripe; $n$ - number of individuals investigated; SD - standard deviation; SE - standard error of arithmetic mean.

(Figs 2I, 5C); body ends somewhat angular providing cells with a rhomboid or triangular appearance, depending on observation perspective; distal portion of preoral dome strongly flattened and thus hyaline, only $2-3 \mu \mathrm{m}$ thick in vivo (Fig. 3A-C, asterisks), projects distinctly in lateral views, forming a right or nearly right angle with main body axis (Fig. 4B, E, opposed arrowheads); postoral body portion unflattened and usually distinctly vaulted (Figs 4A-E, 5B, C). Localization of nuclear apparatus very stable, i.e., between anterior and posterior end of adoral zone and left of cell's midline. Macronucleus broadly ellipsoid (52.4\%), ellipsoid (23.8\%), narrowly ellipsoid $(9.5 \%)$ or globular $(14.3 \%)$, i.e., length:width ratio $1.0-5.0: 1$, size about $8-20 \times 4-9 \mu \mathrm{m}$, usually $12 \times 7 \mu \mathrm{m}$ in protargol preparations; nucleoli $0.5-1 \mu \mathrm{m}$ across. Micronucleus usually attached to anterior portion of right margin of macronucleus; shape and size rather stable, i.e., globular to broadly ellipsoid and $2-3 \mu \mathrm{m}$ in diameter after protargol impregnation (Figs 2A, K, J, M, O-V, 3C, E-H; Table 1). Contractile vacuole in posterior body end, globular to ellipsoid during diastole (Figs 2A, K, O-Q, S-V, 3A, B, D). Cortex flexible, covered by epicortical scales (lepidosomes) usually forming a $1-2 \mu \mathrm{m}$, rarely an up to $4 \mu \mathrm{m}$ thick layer with slimy or fibro-granular appearance in vivo (Fig. 3A, C, D, opposed arrowheads) and flake-like appearance in SEM (Figs 4H, 5A), not recognizable in protargol or silver carbonate preparations. Individual lepidosomes with irregular shape, flat with margin curled up, rather variable in size, viz., $0.50-1.65 \times 0.20$ $0.80 \mu \mathrm{m}$, on average $1.25 \times 0.45 \mu \mathrm{m}$ in SEM (Figs $2 \mathrm{E}$, $4 \mathrm{H}, 5 \mathrm{~A})$. No cortical granules recognizable. Cytoplasm colourless, contains many 3-6 $\mu \mathrm{m}$-sized food vacuoles with bacterial spores; symbiotic bacteria neither 

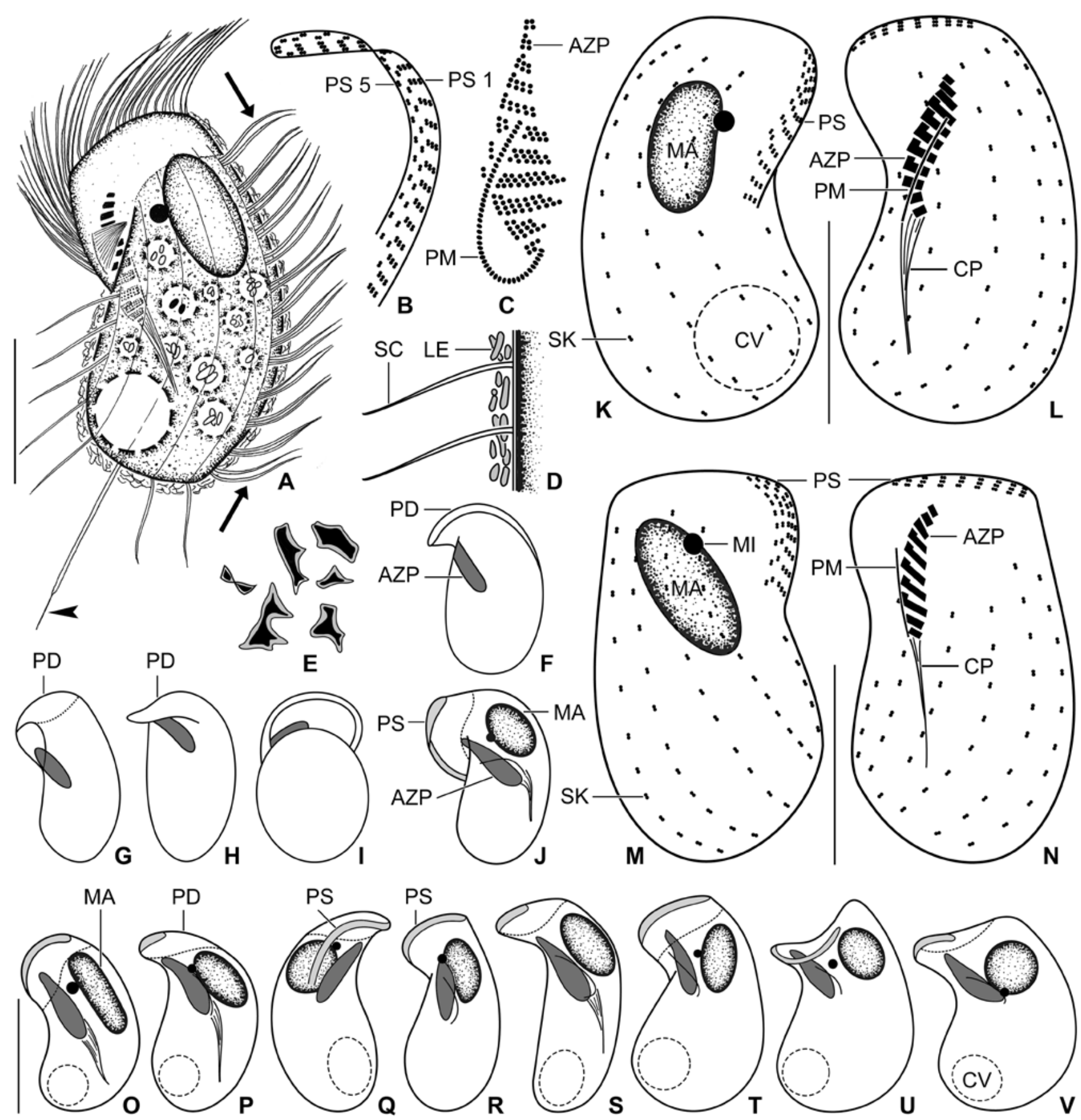

Fig. 2. A-V. Lepidometopus platycephalus from life (A, D, F-I), after silver carbonate (B, C) and protargol (J-V) impregnation, and in the SEM (E). A. Ventrolateral view of a representative specimen, length $45 \mu \mathrm{m}$. Arrows denote left side cilia; arrowhead marks the distally tapered caudal cilium. B. The perizonal stripe is composed of five rows: the first three rows are arranged more closely than the two last rows whose dikinetids are slightly shifted, providing the stripe with a staggered appearance. $\mathbf{C}$. The oral ciliature consists of an average of 11 adoral polykinetids and a paroral membrane optically intersecting the adoral zone. D. Optical section showing the epicortical layer. E. Epicortical scales have various shapes and are about $1.25 \times 0.45 \mu \mathrm{m}$ in size. F-I. Body perspectives. J, O-V. Variability of body shape and size as well as of nuclear apparatus. Dashed line delimits the strongly flattened anterior body portion. Drawn to scale. K-N. Dorso- and ventrolateral views of ciliary pattern and nuclear apparatus of the holotype $(\mathrm{K}, \mathrm{L})$ and of a paratype $(\mathrm{M}, \mathrm{N})$ specimen. AZP - adoral zone of polykinetids; CP - cytopharynx; CV - contractile vacuole; LE - lepidosomes; MA - macronucleus; MI - micronucleus; PD - preoral dome; PM - paroral membrane; PS (1-5) - perizonal stripe (rows); SC - somatic cilium; SK - somatic kineties. Scale bars: $20 \mu \mathrm{m}$. 


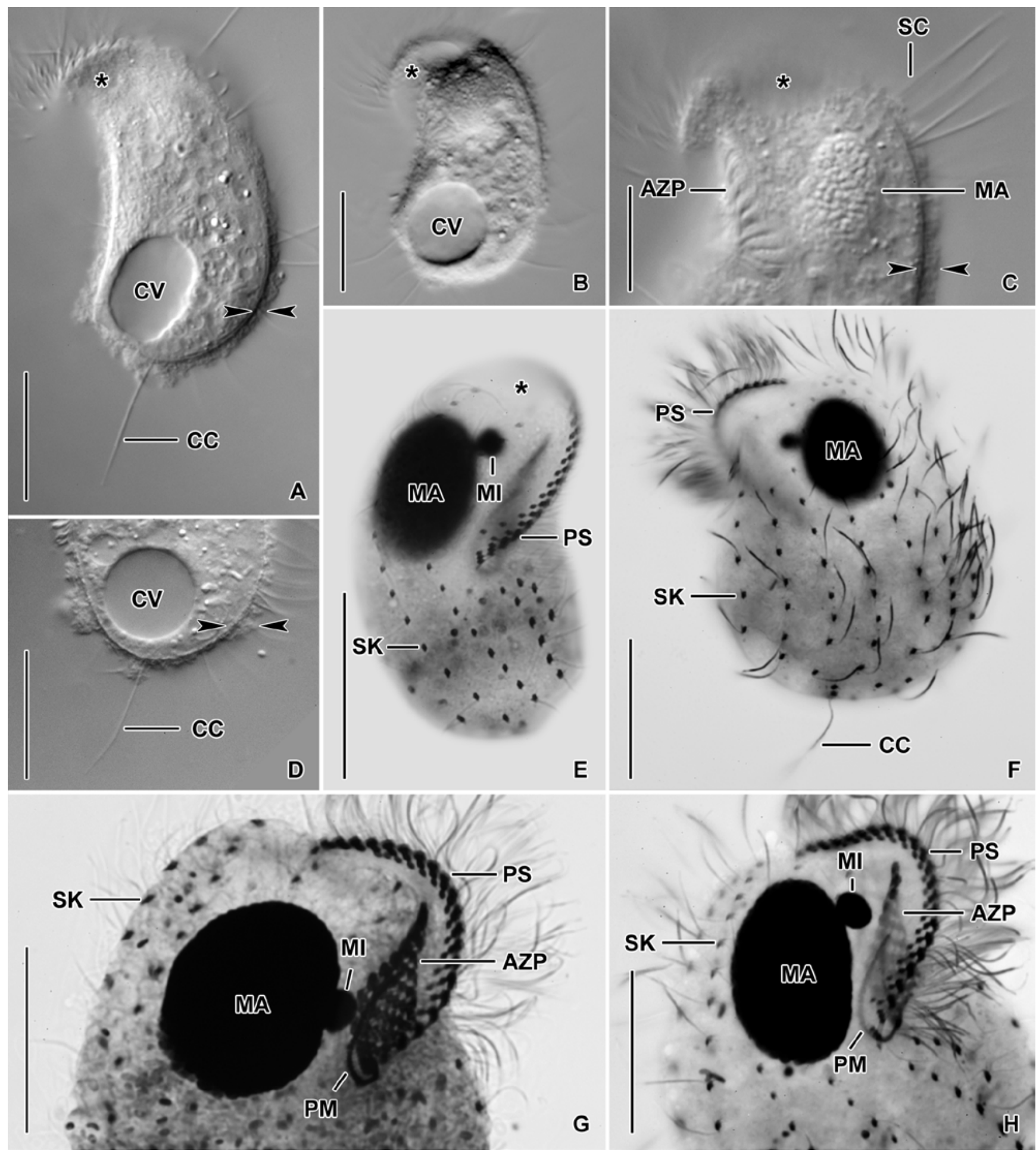

Fig. 3. A-H. Lepidometopus platycephalus from life (A-D) and after silver carbonate impregnation (E-H). Asterisks mark the strongly flattened preoral dome (A-C, E). Opposed arrowheads denote cortex and epicortical scale layer (A, C, D). A, B, E. Ventro- (A, B) and dorsolateral (E) overviews, showing general body organization. C. Detail of anterior body portion. D. Detail of posterior body end, showing the single elongated caudal cilium. F. Lateral view, showing somatic ciliary pattern and nuclear apparatus. G, H. Dorsolateral views of anterior body portion, showing the oral ciliary pattern, the perizonal stripe, and the nuclear apparatus. AZP - adoral zone of polykinetids; $\mathrm{CC}$ - caudal cilium; CV - contractile vacuole; MA - macronucleus; MI - micronucleus; PM - paroral membrane; PS - perizonal stripe; SK - somatic kineties; SC - somatic cilia. Scale bars: $10 \mu \mathrm{m}(\mathrm{C}, \mathrm{G}, \mathrm{H})$ and $20 \mu \mathrm{m}(\mathrm{A}, \mathrm{B}, \mathrm{D}-\mathrm{F})$. 

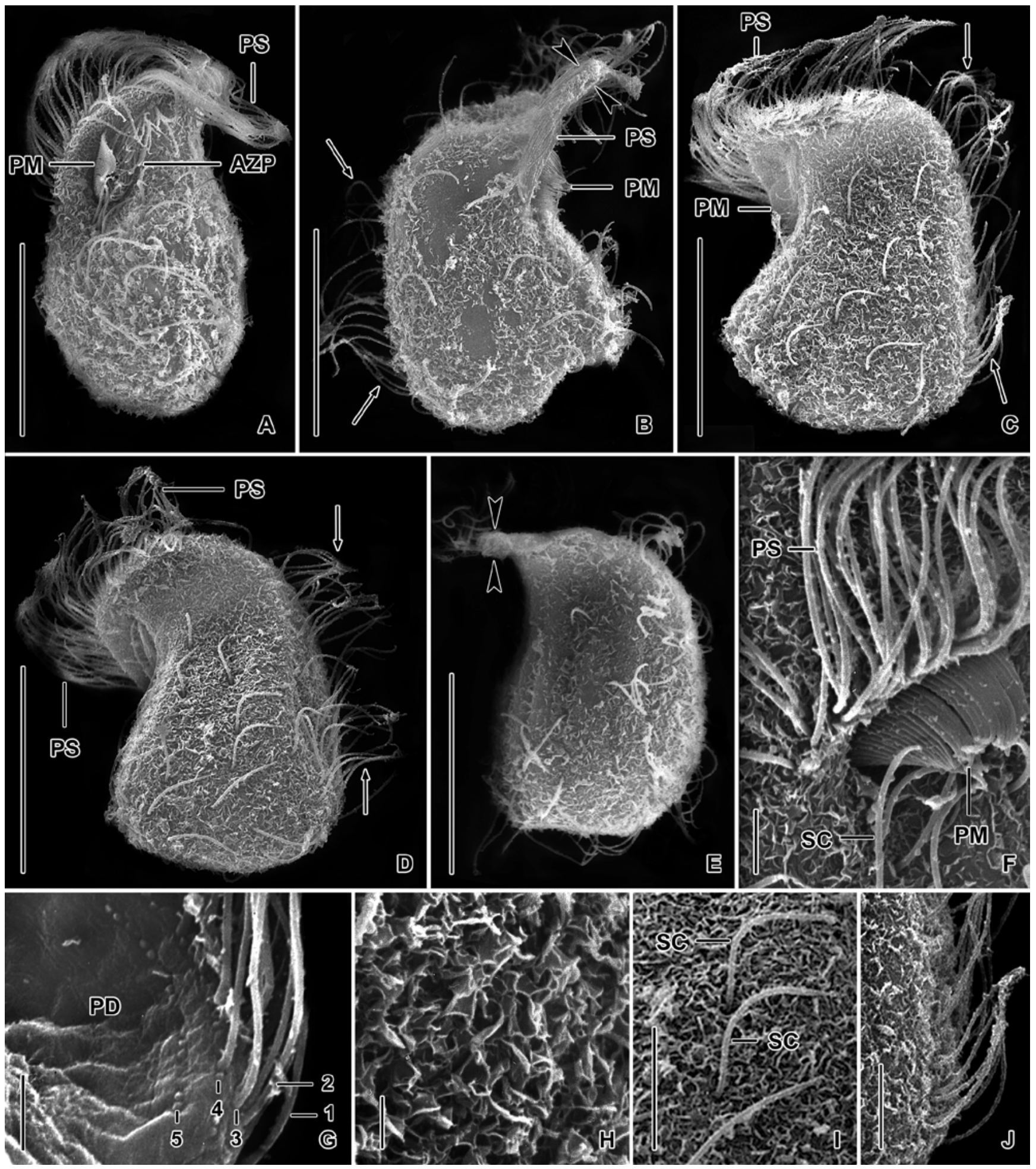

Fig. 4. A-J. Lepidometopus platycephalus in the SEM. A-E. Ventral (A), right side (B), dorsolateral (C, D), and left side (E) overview, showing general body organization. Opposed arrowheads mark the strongly flattened distal portion of the preoral dome (B, E); arrows denote left side cilia (B-D). F. Ventrolateral view, showing the paroral membrane and the perizonal stripe. G. Dorsolateral view, showing five perizonal rows. H. Epicortical scales. I, J. Only a single basal body is ciliated in the postoral dikinetids (I) except for the left side kineties where both basal bodies are ciliated (J). (1-5) - perizonal rows; AZP - adoral zone of polykinetids; PD - preoral dome; PM - paroral membrane; PS - perizonal stripe; SC - somatic cilia. Scale bars: $1 \mu \mathrm{m}(\mathrm{H}), 2 \mu \mathrm{m}(\mathrm{G}), 3 \mu \mathrm{m}(\mathrm{F}), 5 \mu \mathrm{m}(\mathrm{I}, \mathrm{J})$, and $20 \mu \mathrm{m}(\mathrm{A}-\mathrm{E})$. 

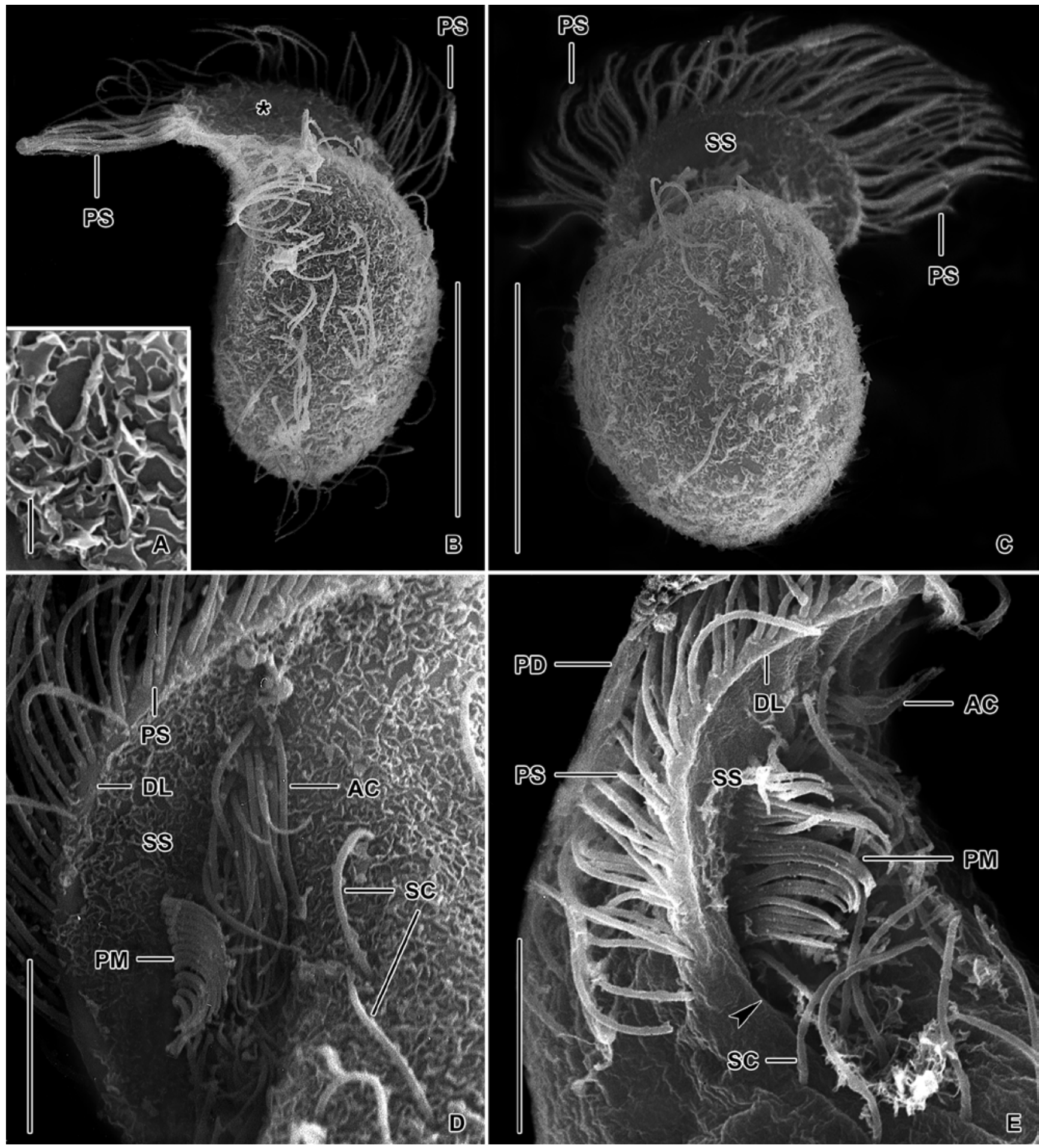

Fig. 5. A-E. Lepidometopus platycephalus in the SEM. A. Epicortical scales (lepidosomes). B. Left side overview, showing the strongly flattened preoral dome (asterisk). C. Oblique posterior polar view, showing the globular postoral portion roofed by the cap-shaped preoral dome. D. Detail of oral area, showing the tongue-like paroral membrane and the adoral zone of polykinetids whose cilia spread backwards. The dome lip is very narrow while the side stripe forms a rather deep channel covered with epicortical scales. E. Ventrolateral view of oral body portion. The arrowhead marks entrance to buccal cavity. This cell lost lepidosomes during the preparation process. AC - adoral cilia; DL - dome lip; PD - preoral dome; PM - paroral membrane; PS - perizonal stripe; SC - somatic cilia; SS - side stripe. Scale bars: $1 \mu \mathrm{m}$ (A), $5 \mu \mathrm{m}(\mathrm{D}, \mathrm{E})$, and $20 \mu \mathrm{m}(\mathrm{B}, \mathrm{C})$. 
detected in vivo nor in protargol preparations (Fig. 3A). Creeps slowly and ungainly on microscope slides, rotates slowly about main body axis when swimming.

Somatic ciliature composed of dikinetids, anterior cilium lacking in postoral kinetids (Fig. 4I) except for those extending along left body margin, an unusual feature observed in vivo, after protargol impregnation, and confirmed in SEM (Figs 2A, 3C, 4B-D, arrows, J). Somatic cilia comparatively widely spaced, rather rigid, in vivo $10-12 \mu \mathrm{m}$ long in mid-body, up to $13 \mu \mathrm{m}$ on rear body end; a single elongated caudal cilium with filiform distal end, 16-30 $\mu \mathrm{m}$ long, usually about $20 \mu \mathrm{m}$ long in vivo, fragile and thus usually missing in prepared specimens (Figs 2A, 3A, D). On average 11 equidistant and ordinarily spaced ciliary rows, i.e., interkinetal distance about 5-6 $\mu \mathrm{m}$ in protargol preparations, follow body curvature (Figs 2K-N, 3E, F; Table 1). Perizonal stripe begins at left anterior body margin, extends along whole anterior body end, curves perpendicularly to right anterior margin, and terminates on right margin of dorsal side at or slightly anterior to level of proximal end of adoral zone, i.e., forms a $\Gamma$-shaped pattern; extends $46 \%$ of body length on average; invariably composed of five rows: first three rows more narrowly spaced than the two last rows with dikinetids slightly shifted, providing stripe with a staggered appearance. Stripe rows segmented into an average of 19 false kineties, each perizonal dikinetid with two cilia $15-18 \mu \mathrm{m}$ long in vivo and $8-12 \mu \mathrm{m}$ in SEM; number of perizonal rows often difficult to determine in distal portion of stripe due to their narrow spacing and strong flattening of anterior body portion, but ontogenetic data indicate that there are five rows beginning at almost same level (Figs 2B, K-N, 3E-H, 4G; Table 1).

Type 4 oral area. Adoral zone extends vertically to strongly obliquely and about half of body length, roofed by preoral dome, composed of an average of 11 polykinetids up to $6 \mu \mathrm{m}$ wide; cilia $5 \mu \mathrm{m}$ long in vivo, usually spread backwards in SEM (Fig. 5D); proximal- and distalmost polykinetids rectangular or somewhat irregular and composed of two to three rows of basal bodies, others L-shaped and usually composed of a short row and three long rows (Fig. 2C). Paroral membrane begins about $17 \mu \mathrm{m}$ posterior to anterior body end, extends along right margin of side stripe, optically intersects adoral zone; composed of narrowly spaced, oblique ellipsoids being dikinetids according to the ontogenetic data, only one basal body ciliated according to SEM observations, cilia 3-6 $\mu \mathrm{m}$ long in SEM, form a tongue-like or fimbriate structure (Figs 2C, L, N, 3G, H, 4F, 5D, E; Table 1). Cytopharyngeal fibres originate from proximal end of adoral zone and paroral membrane, extend backwards forming a funnel about $15 \mu \mathrm{m}$ long in protargol preparations (Fig. 2L, N). Dome lip inconspicuous because only $0.25-0.50 \mu \mathrm{m}$ wide in SEM. Side stripe a comparatively deep, 2.3-3.3 $\mu \mathrm{m}$ wide channel in the scanning electron microscope, covered by epicortical scales (Fig. 5D, E).

\section{Morphogenesis of Lepidometopus platycephalus}

Division mode: Binary fission is homothetogenic and occurs in freely motile (non-encysted) condition. Body shape changes drastically. Stomatogenesis is pleurotelokinetal. The parental oral structures are reorganized but are not involved in the formation of the daughter oral ciliature.

Body changes: Early dividers are $48-55 \times 23-$ $25 \mu \mathrm{m}$ in size, i.e., they are slightly larger than morphostatic specimens and gradually loose the reniform and rhomboid appearance, becoming Metopus-shaped (Fig. 6A-H). The cell portion carrying the prospective adoral polykinetids transforms into a small bulge recognizable in lateral view (Fig. 6E, F). On the other hand, the parental oral area is still unchanged, i.e., the preoral dome is strongly flattened and distinctly projects from body proper (Fig. 6C).

In mid-dividers, the body slightly shortens and conspicuously broadens to $45-50 \times 30-38 \mu \mathrm{m}$. These cells are thus the stoutest and shortest dividers. Body shape drastically changes: (1) the outline becomes broadly elliptic, (2) the ventral side becomes strongly inflated, and (3) the preoral dome turns into a small, rounded protuberance projecting from the left anterior body margin (Fig. 7A-F).

Just before separation, the daughter cells are broadly ellipsoid without any sign of a preoral dome (Fig. $8 \mathrm{~A}, \mathrm{~B})$. However, fundamental changes in cell shape and size take place after division: (1) the body intensively grows from about $33 \times 23 \mu \mathrm{m}$ to about $55 \times 22 \mu \mathrm{m}$, (2) the anterior portion of the cell flattens, and (3) the preoral dome pulls out of the cell to roof the adoral zone by twisting leftwards taking along the perizonal stripe which thus obtains the typical $\Gamma$-shaped pattern (Fig. $8 \mathrm{C}-\mathrm{H})$. Nevertheless, late post-dividers are still very dissimilar from morphostatic cells. They are oblong, not or only slightly twisted anteriorly (Fig. 8G, H), and longer than morphostatic specimens (on average 55 $\times 22 \mu \mathrm{m}$ vs. $38 \times 20 \mu \mathrm{m}$ in protargol preparations). This indicates that their further development must be associated with body shortening, possibly as a consequence of massive remodelling to a reniform/rhomboid shape. 

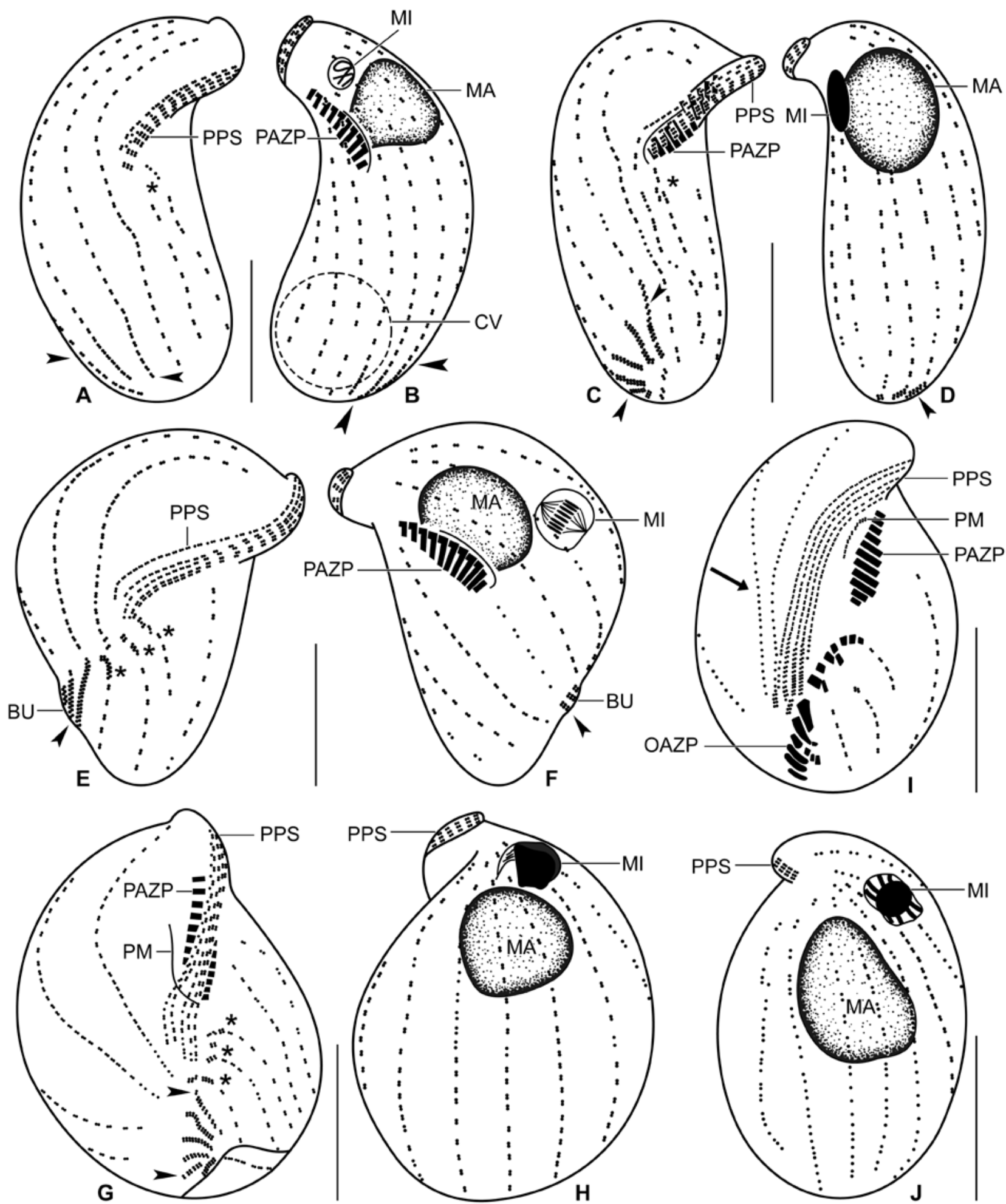

Fig. 6. A-J. Lepidometopus platycephalus, ciliary pattern and nuclear apparatus of early dividers (A-H) and of an early mid-divider (I, J) after protargol impregnation. Arrowheads mark the prospective adoral polykinetids formed at the posterior end of dorsal and dorsolateral kineties. Asterisks denote the prospective adoral polykinetids developing at the anterior end of the postoral kineties. Arrow in (I) points to two dorsolateral kineties which migrate towards the growing perizonal stripe to become perizonal rows 4' and 5' in the opisthe. BU - bulge; $\mathrm{CV}$ - contractile vacuole; MA - macronucleus; MI - dividing micronucleus; OAZP - opisthe's adoral zone of polykinetids; PAZP - proter's adoral zone of polykinetids; PM - paroral membrane; PPS - proter's perizonal stripe. Scale bars: $20 \mu \mathrm{m}$. 

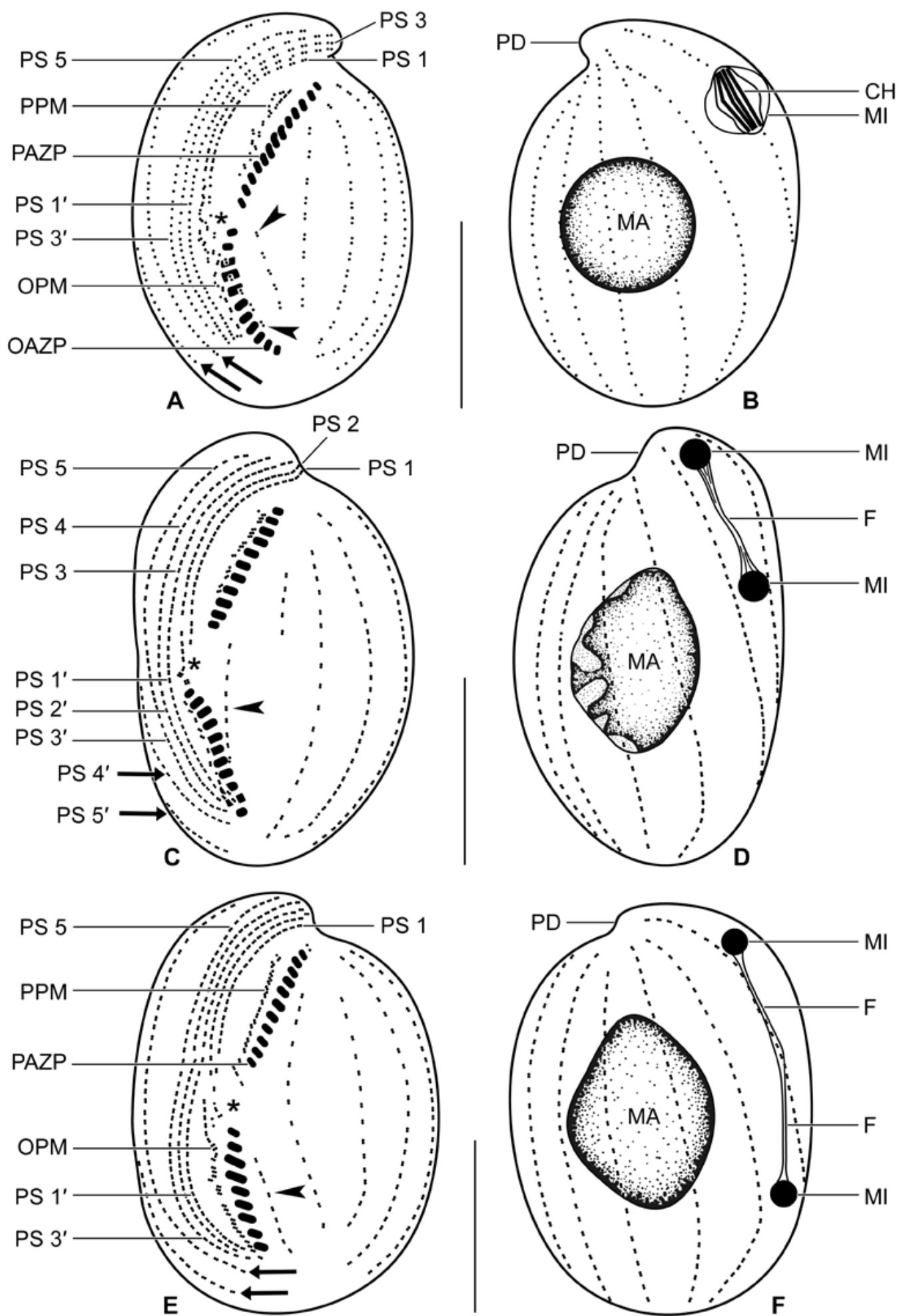

Fig. 7. A-F. Lepidometopus platycephalus, ciliary pattern and nuclear apparatus of mid-dividers after protargol impregnation. Asterisks denote scattered dikinetids of perizonal rows 1 and 2 that migrate along the new adoral zone to assemble the opisthe's paroral membrane. Arrows point to two dorsolateral kineties which migrate towards the opisthe's perizonal stripe to become rows 4' and 5'. Arrowheads mark newly formed ciliary rows left of opisthe's adoral zone. CH - chromosomes; F - fibres; MA - macronucleus; MI - micronucleus; OAZP - opisthe's adoral zone; OPM - opisthe's paroral membrane; PAZP - proter's adoral zone; PD - preoral dome; PPM - proter's paroral membrane; PS - perizonal stripe rows. Scale bars: $20 \mu \mathrm{m}$. 

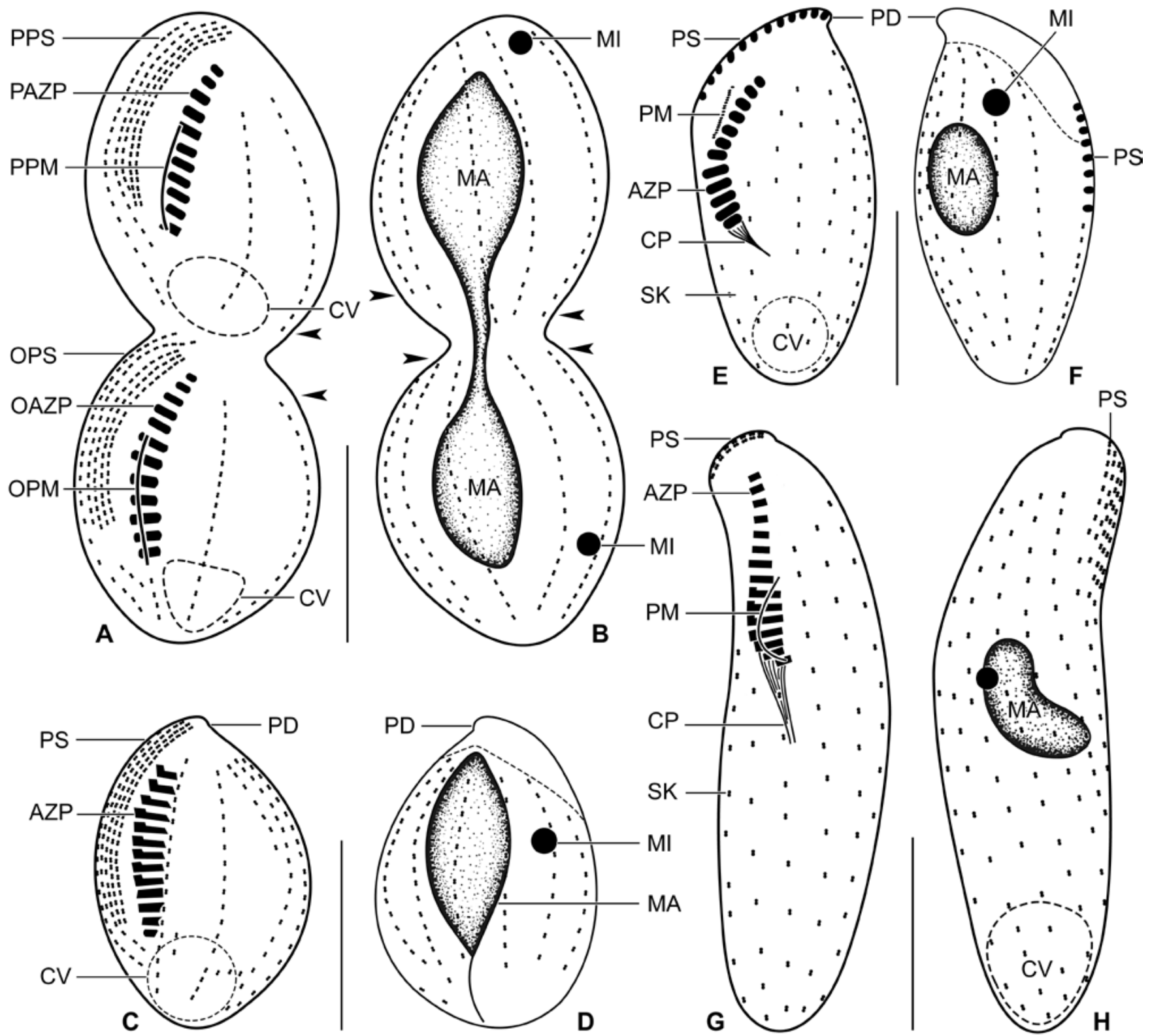

Fig. 8. A-H. Lepidometopus platycephalus, ciliary pattern and nuclear apparatus of a late divider (A, B), early post-dividers (C-F), and a late post-divider $(\mathrm{G}, \mathrm{H})$ in protargol preparations. Arrowheads in $(\mathrm{A}, \mathrm{B})$ mark barren area that forms at the posterior end of the proter and at the anterior end of the opisthe after the parental somatic ciliary rows split in the middle. Dashed lines in $(\mathrm{D}, \mathrm{F})$ delimit the flattened anterior body portion, i.e., the preoral dome. AZP - adoral zone of polykinetids; CP - cytopharynx; CV - contractile vacuole; MA - macronucleus; MI - micronucleus; OAZP - opisthe's adoral zone of polykinetids; OPM - opisthe's paroral membrane; OPS - opisthe's perizonal stripe; PAZP - proter's adoral zone of polykinetids; PD - preoral dome; PM - paroral membrane; PPM - proter's paroral membrane; PPS - proter's perizonal stripe; PS - perizonal stripe; SK - somatic kineties. Scale bars: $20 \mu \mathrm{m}$.

Development of adoral zone: The formation of the opisthe's adoral zone is associated with two concomitantly proceeding events taking place in early dividers: (1) proliferation of dikinetids (protopolykinetids) in the posterior portion of about six dorsal and dorsolateral ki- neties (Fig. 6A-G, arrowheads) and (2) the production of dikinetids in the anterior portion of about three postoral kineties, i.e., slightly posterior to the proximal end of the perizonal stripe (Fig. 6A, C, E, G, asterisks). In early mid-dividers, the newly formed dikinetids detach 
from the somatic ciliary rows and migrate to assemble the opisthe's adoral zone (Fig. 6I). The new adoral polykinetids are thus migrating kinetofragments composed of two long rows of basal bodies. The third long row and the short row making the polykinetids L-shaped are mostly added in post-dividers (Fig. 8C, G).

Reorganization of the parental adoral zone begins in early mid-dividers. The polykinetids of the proter become smaller and loose the interphase L-shaped pattern, very likely due to the resorption of one long row and the short row of basal bodies (Fig. 6I). Taking into account that the adoral zone of proter and opisthe has a similar morphology in mid-dividers and late dividers (Figs 7A, C, E, 8A), the proter's adoral zone must obtain the species-specific pattern also post-divisionally.

Development of perizonal stripe and paroral membrane: During the formation of the new adoral polykinetids, an intrakinetal proliferation of kinetids commences in the parental perizonal rows which thus elongate posteriorly into the glabrous area between the opisthe's adoral zone and the posterior end of the split parental somatic kineties (Fig. 6E, G, I). In middividers, the posterior portion of perizonal rows 1 and 2 disorders and the resulting dikinetids migrate along the new adoral zone to assemble the opisthe's paroral membrane (Fig. 7A, C, E, asterisks); perizonal rows 3-5 remain ordered and their posterior portion becomes perizonal rows 1' -3 ' in the opisthe. Opisthe's perizonal rows 4' and 5' are formed from the posterior half of the first two dorsolateral kineties which migrate towards perizonal rows 1' -3 ' in very late mid-dividers and late dividers (Figs 6I, 7A, C, E, arrows). The loss of these two dorsolateral kineties is compensated by the formation of one or two ciliary rows left of the opisthe's adoral zone (Fig. 7A, C, E, arrowheads).

In connection with body re-shaping, the parental perizonal stripe looses the $\Gamma$-shape and moves from dorsolateral to the right margin of the ventral side; the species-specific pattern is obtained post-divisionally. The parental paroral membrane is entirely disordered in mid-dividers (Fig. 7A, C, E) and re-assembled in late dividers (Fig. 8A).

Development of somatic ciliature: After formation of the prospective adoral polykinetids, an intense proliferation of basal bodies begins in all somatic ciliary rows. First, the basal bodies of the individual dikinetids go apart more or less distinctly. Then a new basal body develops in front of the anterior basal body generating a triad. Subsequently, a fourth basal body forms ahead of the posterior basal body producing a tetrad. Eventu- ally, the tetrad splits into two pairs of dikinetids. The replication of dikinetids finishes in mid-dividers, i.e., when all somatic ciliary rows are arranged meridionally and composed of comparatively narrowly spaced dikinetids (Fig. 7C-F). In late dividers, the somatic ciliary rows split in the middle leaving a barren area at the posterior region of the proter and at the anterior region of the opisthe (Fig. 8A, B, arrowheads). The somatic dikinetids are still narrowly arranged in early post-dividers (Fig. 8C, D). Their loose spacing is obtained gradually by growth and patterning of the body (Fig. 8G, H).

Nuclear division: In early dividers, the macronucleus is as in morphostatic cells, i.e., it is oblong and situated between the anterior and posterior end of the adoral zone (Fig. 6B, D, F, H). Later on, the macronucleus becomes larger, rounds up, and migrates to mid-body (Fig. $6 \mathrm{~J})$. In mid-dividers, the centrally located macronucleus becomes broadly fusiform and begins to divide (Fig. 7B, $\mathrm{D}, \mathrm{F})$. In late dividers, the macronucleus is dumbbellshaped with a conspicuous constriction in the fission area (Fig. 8 B). After binary fission, the macronucleus is lenticular and pointed (Fig. 8D). During post-divisional growth, the macronucleus becomes oblong and moves to the species-specific interphase position (Fig. 8F, H).

When division commences, the micronucleus increases in size from $2.5 \mu \mathrm{m}$ to $4.0 \mu \mathrm{m}$, showing fibrous structures, possibly prophasic chromosomes (Fig. 6B). The micronucleus further enlarges to about $6 \mu \mathrm{m}$ and impregnates heterogeneously, which is indicative of the formation of spindle microtubules (Fig. 6D, H, J). Thus, the division spindle and the metaphase plate made of about eight chromosomes, become distinct already in early dividers (Fig. 6F). When the macronucleus becomes globular, the micronucleus begins to divide (Fig. 7B). The daughter micronuclei impregnate homogenously and are connected by a fiber bundle that conspicuously elongates in mid-dividers (Fig. 7D, F). The bundle disappears and the micronucleus achieves the species-specific size already in late dividers (Fig. 8B). During post-divisional patterning, the micronucleus moves to the macronucleus (Fig. 8D, F, H).

\section{DISCUSSION}

\section{The new genus Lepidometopus}

Lepidometopus differs from all described metopids in having the body coated by epicortical scales (lepidosomes). Such peculiar structures are present also in 
trachelophyllids where their morphologies have been used to define particular genera (Nicholls and Lynn 1984; Foissner et al. 2002; Foissner 2005a, 2016b). Lepidosomes have been detected also on resting cysts of some oligotrichs, hypotrichs, and even colpodids, for instance, in Meseres corlissi (Foissner 2005b), Halteria grandinella, Oxytricha granulifera, Colpoda inflata, and C. lucida (Foissner et al. 2007). The scales of Lepidometopus are simple, flat structures without ornamentation. On the other hand, the epicortical scales of trachelophyllids are complex and ornamented while they are conical or tubular in resting cysts of oligotrichs, some hypotrichs, and colpodids. This indicates an independent origin of lepidosomes in various ciliate lineages, as already suggested by Foissner (2005b).

Lepidometopus is further outstanding within the family Metopidae Kahl, 1927 in that it has lost the typical metopid shape. Its body is reniform with somewhat angular margins that provide the ciliate with a remarkable, rhomboid appearance in ventrolateral and dorsolateral views. Moreover, the strongly flattened distal portion of the preoral dome distinctly projects laterally forming a right angle with the main body axis (Fig. 1). In this respect Lepidometopus resembles two insufficiently known genera, Palmarella Jankowski, 1975 [substitute name of the preoccupied Palmarium Gaievskaïa, 1925; for details see Aescht (2001)] and Tesnospira Jankowski, 1964b.

Identity and taxonomic affiliation of Palmarella are problematic and require re-description of the type species "Palmarium salinum Gaievskaïa, 1925". Gaievskaïa (1925) considered Palmarella as a hypotrich while Kahl (1932) classified it as a heterotrich with affinities either to Condylostoma or small Metopus species. Jankowski (1964a, b) speculated that it could be between Metopus Claparède and Lachmann, 1858 and Tropidoatractus Levander, 1894. He also transferred three further species to Palmarella: Metopus angustus Kahl, 1927; M. latus Kahl, 1927; and M. mucicola Kahl, 1927. Gaievskaïa's and Jankowski's illustrations of Palmarella resemble some body shapes observed in Lepidometopus. Indeed, both genera can be reliably separated only by the presence/absence of a mucilaginous body cover at the present state of knowledge. We argue that lepidosomes were not overlooked in the aforementioned Palmarella/Metopus species because Kahl (1930, 1932) recognized a mucous coat in trachelophyllids and mucilaginous houses in P. mucicola (= M. mucicola). Although $P$. mucicola cells are not covered by a mucilaginous layer after leaving their houses, we cannot ex- clude that this species represents a transition between Palmarella and Lepidometopus or that it belongs to Lepidometopus. As concerns P. lata (= M. latus), Jankowski $(1964 a, b)$ did not mention any mucilaginous layer in his redescription and no epicortical layer is recognizable in a photograph of that species in Bourland et al. (2014), who used a high-power oil immersion objective.

Tesnospira can be clearly separated from Lepidometopus by the very short and inconspicuous perizonal stripe as well as by the suture formed by the ciliary rows in the anterior pole area. Moreover, Tesnospira lacks a side stripe, i.e., there is no cilia-free area between adoral zone and perizonal stripe (Jankowski 1964a, b). On the other hand, Lepidometopus has a well-developed perizonal and side stripe but does not exhibit a suture in the anterior body area.

\section{The new species Lepidometopus platycephalus}

The most prominent features of L. platycephalus include the reniform and somewhat rhomboid body, the macronucleus situated in the anterior body half, the strongly flattened preoral dome, and the type 4 oral area. There are several insufficiently described species with strongly flattened anterior body portion and possibly also with a type 4 oral area: Palmarella salina (Gaievskaïa, 1925) Jankowski, 1975; P. lata (Kahl, 1927) Jankowski, 1975; P. mucicola (Kahl, 1927) Jankowski, 1975; P. angusta (Kahl, 1927) Jankowski, 1975; and Tesnospira alba Jankowski, 1964b.

Palmarella salina and P. lata resemble L. platycephalus in the small body size, the loose ciliature, and the elongated caudal cilium. However, they have a different body shape and the macronucleus is located centrally. Moreover, $P$. salina lives in hyper-saline environments. Palmarella mucicola forms mucilaginous houses, lacks elongated caudal cilia, and the macronucleus is in mid-body. Palmarella angusta differs from L. platycephalus by the broadly fusiform and densely ciliated body, the multiple caudal cilia, and the centrally situated macronucleus. Tesnospira alba can be distinguished from L. platycephalus by the slightly larger body $(70 \mu \mathrm{m}$ vs. $35-50 \mu \mathrm{m})$, the localization of the macronucleus (in mid-body vs. in anterior body half), the higher number of ciliary rows ( 24 vs. 11 ), and the much shorter adoral zone extending about one fifth vs. one half of body length.

\section{Morphogenesis}

Although the interphase morphology of L. platycephalus is rather different from that of typical me- 
topids, its morphogenesis follows the metopid mode as described by Foissner and Agatha (1999): (1) the body undergoes fundamental re-shaping, (2) the parental oral structures are reorganized but do not contribute to the daughter oral ciliature, (3) the opisthe's adoral polykinetids originate pleurotelokinetally as migrating kinetofragments that detach from the posterior end of dorsal and dorsolateral kineties as well as from the anterior end of postoral kineties, (4) the opisthe's paroral membrane is formed from the dissociated posterior portion of two perizonal rows, and (5) the opisthe's perizonal stripe has a hybrid origin, i.e., it is formed by three parental perizonal rows and two dorsolateral ciliary rows.

The morphogenetic processes of metopids show only minor differences that concern (1) the number of postoral and dorsal kineties involved in the production of adoral polykinetids, (2) the extent of reorganization of the parental adoral zone and paroral membrane, (3) the timing of disappearance of the preoral dome, (4) modifications of the posterior body end, and (5) changes in the position of the macronucleus (Table 2).

\section{Phylogeny}

The armophoreans are a "riboclass", i.e., a molecular class for which morphological synapomorphies are not known (Lynn 2004). Lynn (2008) subdivided the Armophorea Lynn, 2004 into two orders: Armophorida Jankowski, 1964b and Clevelandellida Puytorac and Grain, 1976. The armophorids are considered as freeliving anaerobes carrying a perizonal stripe of four or five rows, an adoral zone composed of paramembranelles, and a paroral membrane made of a single file of dikinetids. The clevelandellids are endocommensals in the digestive tract of various invertebrates and vertebrates; they lack a perizonal stripe, the adoral zone is composed of heteromembranelles, and the paroral membrane is made of two files of oral kinetosomes separated by a ridge (for a review, see Lynn 2008). However, the phylogenetic relationships among and within these orders conflict with the morphology-based classification. The armophorid family Metopidae Kahl, 1927 is consistently depicted as paraphyletic since it includes the monophyletic order Clevelandellida. The "Metopidae + Clevelandellida" assemblage is very likely related to the class Litostomatea (Vd'ačný et al. 2010; Lynn and Wright 2013; Paiva et al. 2013; Bourland et al. 2014, 2017; da Silva-Neto et al. 2015; Li et al. 2016, 2017). On the other hand, the armophorid family Caenomorphidae Poche, 1913 could be a sister group of the "Metopidae + Clevelandellida" cluster or, more likely, could have diverged at the base of the Spirotrichea or the Intramacronucleata (Paiva et al. 2013). Thus, the class Armophorea is very likely non-monophyletic with caenomorphids not being closely related to metopids + clevelandellids within the "SAL" (Spirotrichea + Armophorea + Litostomatea) supercluster recognized from extensive molecular datasets (Gentekaki et al. 2014, 2017; Gao et al. 2016).

Our morphogenetic data corroborate the phylogenetic analyses very well. Thus, the ontogenesis of caenomorphids and metopids is only superficially similar and does not corroborate a monophyly of the Armophorida. Originally, this order contained only the caenomorphids (Jankowski 1964b, 1980), later the metopids were added by Small and Lynn (1985) and Puytorac (1994), who very likely assumed homology of the caenomorphid and metopid perizonal stripe. However, not only the fine structure but also the ontogenetic function and origin of the perizonal stripe are so different in caeonomorphids and metopids that homology is unlikely. The caenomorphid stripe generates adoral polykinetids, the paroral membrane and the perizonal stripe for the opisthe. Specifically, the new adoral polykinetids and the new paroral membrane are derived from the posterior end of numerous "false kineties" of the parental perizonal stripe, and the new perizonal stripe originates by proliferation at the anterior end of all parental perizonal rows (Martín-Gonzáles et al. 1987; Table 2). In contrast, the metopid stripe does not generate adoral polykinetids, the new paroral membrane is formed from the dissociated posterior portion of only two perizonal rows, and the new perizonal stripe has a hybrid origin, i.e., it is formed by three parental perizonal rows and two dorsolateral ciliary rows (Foissner and Agatha 1999, present study). Moreover, caenomorphids undergo a complex binary fission reminiscent of the enantiotropic division of oligotrich spirotricheans (Martín-Gonzáles et al. 1987). On the other hand, the metopid division is clearly homothetogenic (Foissner and Agatha 1999, present study). Therefore, we support the ordinal rank proposed for metopids by Foissner and Agatha (1999).

Although the data on morphogenesis of clevelandellids are rather incomplete, they support the metopid kinship rather well. Like in metopids, the clevelandellid stomatogenesis is pleurotelokinetal, i.e., the new adoral polykinetids originate from some somatic kineties in the posterior cell region (Santos et al. 1986; Table 2). Since clevelandellids do not possess a perizonal stripe, their paroral membrane originates from ordinary somatic 


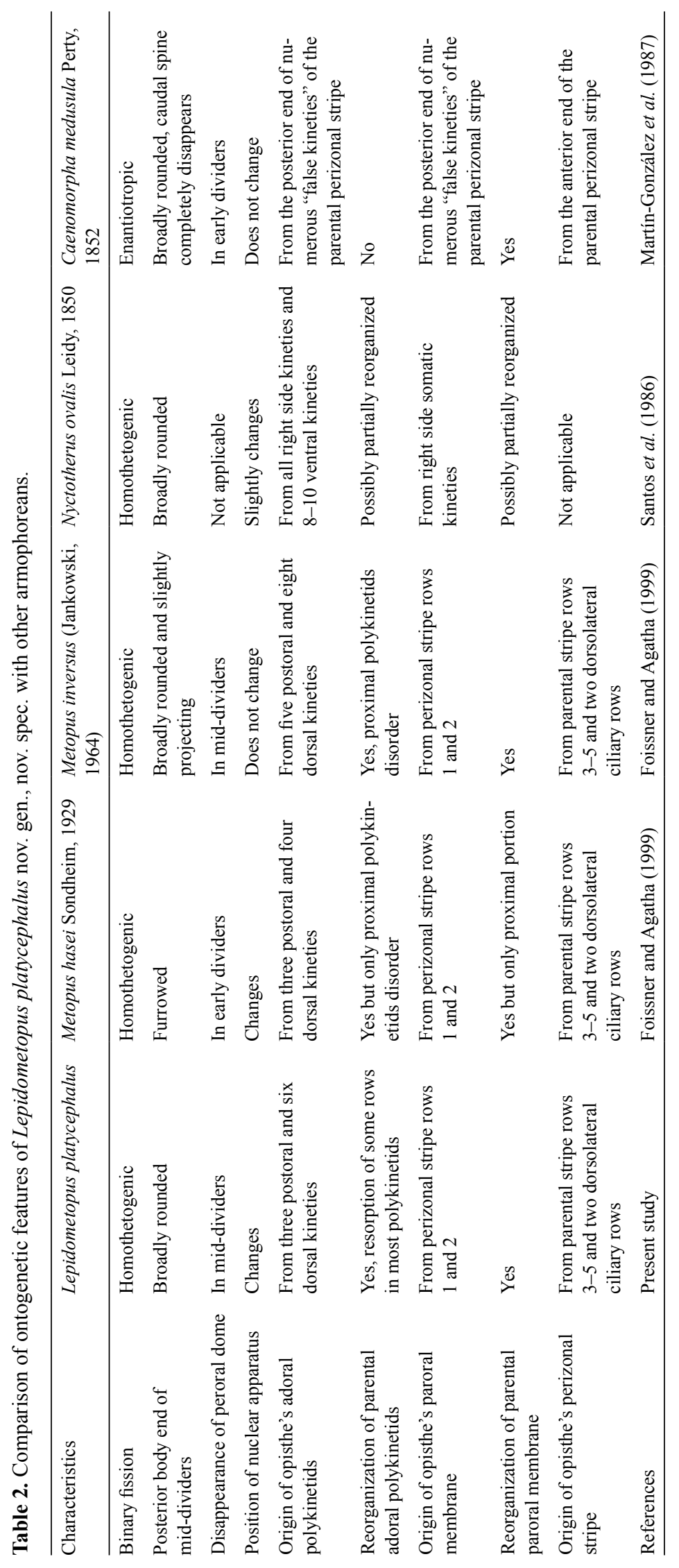


ciliary rows. Interestingly, the paroral dikinetids arrange into two parallel files during clevelandellid stomatogenesis, which might be a reminiscence of the formation of the metopid paroral membrane from two perizonal rows. In this light, clevelandellids can be considered as a metopid lineage that lost the perizonal stripe very likely in connection with the endobiotic lifestyle.

Although metopids and litostomateans are morphologically very dissimilar, Vd'ačný et al. (2010) assembled morphogenetic evidence that they could have a common ancestry. Specifically, (1) the stomatogenesis is purely somatic and telokinetal, (2) the proliferation of basal bodies commences in the dorsal and dorsolateral kineties, (3) the paroral membrane of metopids and the circumoral kinety of litostomateans originates from kinetofragments detaching from somatic kineties and uniting to a single kinety, and (4) the adoral polykinetids of metopids and the preoral kineties (adesmokineties) of dileptids and spathidiids are migrating kinetofragments of somatic origin (Foissner and Xu 2007, Vd'ačný and Foissner 2012). In contrast, spirotricheans, the other group belonging to the SAL superclade, have an apokinetal stomatogenesis, proliferation of basal bodies begins on the ventral side, the new paroral membrane originates from an oral primordium, and the new adoral polykinetids differentiate from the oral primordium and are thus not migrating kinetofragments (Foissner 1996). Whether these morphogenetic features of metopids and litostomateans are plesiomorphies of the last common ancestor of the SAL supercluster or synapomorphies supporting our Lamellicorticata hypothesis (Vd'ačný et al. 2010) requires further investigations.

Acknowledgements. We are grateful to Dr. Barbara Harl and Robert Schörghofer for technical assistance. Financial support was provided by the Austrian Science Fund (FWF Project P26325_B16) and the Wilhelm and Ilse Foissner Stiftung. This work was supported also by the Slovak Research and Development Agency under the contract No. APVV-15-0147 and by the Grant Agency of the Ministry of Education, Science, Research and Sport of the Slovak Republic and Slovak Academy of Sciences under the Grant VEGA 1/0041/17.

\section{REFERENCES}

Aescht E. (2001) Catalogue of the generic names of ciliates (Protozoa, Ciliophora). Denisia 1: 1-350

Bourland W. A., Wendell L. (2014) Redescription of Atopospira galeata (Kahl, 1927) nov. comb. and A. violacea (Kahl, 1926) nov. comb. with redefinition of Atopospira Jankowski, 1964 nov. stat. and Brachonella Jankowski, 1964 (Ciliophora, Armophorida). Eur. J. Protistol. 50: 356-372
Bourland W. A., Wendell L., Hampikian G. (2014) Morphologic and molecular description of Metopus fuscus Kahl from North America and new rDNA sequences from several metopids (Armophorea, Metopidae). Eur. J. Protistol. 50: 213-230

Bourland W., Rotterová J., Čepička I. (2017) Redescription and molecular phylogeny of the type species for two main metopid genera, Metopus es (Müller, 1776) Lauterborn, 1916 and Brachonella contorta (Levander, 1894) Jankowski, 1964 (Metopida,Ciliophora), based on broad geographic sampling. Eur. J. Protistol. 59: 133-154

Claparède E., Lachmann J. (1858) Études sur les infusoires et les rhizopodes. Mém. Inst. Natn. Génev. 5: 1-260

da Silva-Neto I. D., Paiva T. da S., do Nascimento Borges B., Harada M. L. (2015) Fine structure and molecular phylogeny of Parametopidium circumlabens (Ciliophora: Armophorea), endocommensal of sea urchins. J. Eukaryot. Microbiol. 63: 46-51

Esteban G., Fenchel T., Finlay B. (1995) Diversity of free-living morphospecies in the ciliate genus Metopus. Arch. Protistenkd. 146: $137-164$

Foissner W. (1991) Basic light and scanning electron microscopic methods for taxonomic studies of ciliated protozoa. Eur. J. Protistol. 27: 313-330

Foissner W. (1996) Ontogenesis in ciliated protozoa, with emphasis on stomatogenesis. In: Ciliates: Cells as Organisms, (Eds. K. Hausmann, B. C. Bradbury). Fischer Verlag, Stuttgart, Jena, New York, 95-177

Foissner W. (1998) An updated compilation of world soil ciliates (Protozoa, Ciliophora), with ecological notes, new records, and descriptions of new species. Eur. J. Protistol. 34: 195-235

Foissner W. (2005a) Two new "flagship" ciliates (Protozoa, Ciliophora) from Venezuela: Sleighophrys pustulata and Luporinophrys micelae. Eur. J. Protistol. 41: 99-117

Foissner W. (2005b) The unusual, lepidosome-coated resting cyst of Meseres corlissi (Ciliophora: Oligotrichea): transmission electron microscopy and phylogeny. Acta Protozool. 44: 217-230

Foissner W. (2014) An update of 'basic light and scanning electron microscopic methods for taxonomic studies of ciliated protozoa'. Int. J. Syst. Evol. Microbiol. 64: 271-292

Foissner W. (2016a) Protists as bioindicators in activated sludge: identification, ecology and future needs. Eur. J. Protisol. 55: 75-94

Foissner W. (2016b) Terrestrial and semiterrestrial ciliates (Protozoa, Ciliophora) from Venezuela and Galápagos. Denisia 35: 1-912

Foissner W. (2016c) Heterometopus meisterfeldi nov. gen., nov. spec. (Protozoa, Ciliophora), a new metopid from Australia. Eur. J. Protistol. 55: 118-127

Foissner W., Agatha S. (1999) Morphology and morphogenesis of Metopus hasei Sondheim, 1929 and M. inversus (Jankowski, 1964) nov. comb. (Ciliophora, Metopida). J. Eukaryot. Microbiol. 46: 174-193

Foissner W., Xu K. (2007) Monograph of the Spathidiida (Ciliophora, Haptoria). Vol. I: Protospathidiidae, Arcuospathidiidae, Apertospathulidae. Monograph. Biol. 81: 1-485

Foissner W., Berger H., Kohmann F. (1992) Taxonomische und ökologische Revision der Ciliaten des Saprobiensystems - Band II: Peritrichia, Heterotrichida, Odontostomatida. Informationsberichte des Bayerischen Landesamtes für Wasserwirtschaft 5/92: $1-502$

Foissner W., Agatha S., Berger H. (2002) Soil ciliates (Protozoa, Ciliophora) from Namibia (Southwest Africa), with emphasis on two contrasting environments, the Etosha region and the Namib Desert. Denisia 5: 1-1459 
Foissner W., Müller H., Agatha S. (2007) A comparative fine structural and phylogenetic analysis of resting cysts in oligotrich and hypotrich Spirotrichea (Ciliophora). Eur. J. Protistol. 43: 295-314

Gaievskaïa N. (1925) Sur deux nouveaux infusoires des mares salées - Cladotricha koltzowii nov. gen. nov. sp. et Palmarium salinum nov. gen. nov. sp. Russk. Arkh. Protist. 4: 255-288

Gao F., Warren A., Zhang Q., Gong J., Miao M., Sun P., Xu D., Huang J., Yi Z., Song W. (2016) The all-data-based evolutionary hypothesis of ciliated protists with a revised classification of the phylum Ciliophora (Eukaryota, Alveolata). Sci. Rep. 6: 24874

Gentekaki E., Kolisko M., Boscaro V., Bright K. J., Dini F., Di Giuseppe G., Gong Y., Miceli C., Modeo L., Molestina R. E., Petroni G., Pucciarelli S., Roger A. J., Strom S. L., Lynn D. H. (2014) Large-scale phylogenomic analysis reveals the phylogenetic position of the problematic taxon Protocruzia and unravels the deep phylogenetic affinities of the ciliate lineages. Mol. Phylogenet. Evol. 78: 36-42

Gentekaki E., Kolisko M., Gong Y., Lynn D. (2017) Phylogenomics solves a long-standing evolutionary puzzle in the ciliate world: The subclass Peritrichia is monophyletic. Mol. Phylogenet. Evol. 106: 1-5

$\mathrm{Hu}$ X. (2014) Ciliates in extreme environments. J. Eukaryot. Microbiol. 61: $410-418$

International Commission on Zoological Nomenclature [ICZN] (1999) International Code of Zoological Nomenclature. $4^{\text {th }}$ ed. Tipografia La Garangola, Padova

Jankowski A. W. (1964a) Morphology and evolution of Ciliophora. III. Diagnoses and phylogenesis of 53 sapropelebionts, mainly of the order Heterotrichida. Arch. Protistenkd. 107: 185-294

Jankowski A. W. (1964b) Morfologiâ i èvolûciâ Ciliophora. I. Novaâ sistema sapropelebiotičeskih Heterotrichida [Morphology and evolution of Ciliophora. I. The new system of sapropelebiotic Heterotrichida]. Zool. Zh. 43: 503-517 (in Russian with English title translation and summary)

Jankowski A. W. (1975) Konspekt novoj sistemy podtipa Ciliophora Doflein, 1901 [A conspectus of the new system of the subphylum Ciliophora Doflein, 1901]. In: Account of scientific sessions on results of scientific work: Abstracts of reports, (Ed. U. S. Balašov). Akademiâ Nauk SSSR, Zool. Inst., Leningrad, 26-27 (in Russian)

Jankowski A. W. (1980) Konspekt novoj sistemy tipa Ciliophora [Conspectus of a new system of the phylum Ciliophora]. Trudy Zool. Inst. (Leningr.) 94: 103-121 (in Russian)

Jankowski A. W. (2007) Tip Ciliophora Doflein, 1901 [Phylum Ciliophora Doflein, 1901]. In: Protisty: Rukovodstvo po zoologii, č. 2 [Protista: Handbook of Zoology, $2^{\text {nd }}$ part], (Ed. A. F. Alimov). Nauka, St. Petersburg, 415-993 (in Russian with English title translation)

Kahl A. (1927) Neue und ergänzende Beobachtungen heterotricher Ciliaten. I. Arch. Protistenkd. 57: 121-203

Kahl A. (1930) Urtiere oder Protozoa I: Wimpertiere oder Ciliata (Infusoria) 1. Allgemeiner Teil und Prostomata. Tierwelt Dtl. 18: $1-180$

Kahl A. (1932) Urtiere oder Protozoa I: Wimpertiere oder Ciliata (Infusoria) 3. Spirotricha. Tierwelt Dtl. 25: 399-650

Levander K. M. (1894) Materialien zur Kenntniss der Wasserfauna in der Umgebung von Helsingfors, mit besonderer Berücksichtigung der Meeresfauna. I. Protozoa. Acta Soc. Fauna Flora Fenn. 12: 1-115

Li M., Sun Z.-Y., Grim J. N., Ponce-Gordo F., Wang G.-T., Zou H., Li W.-X., Wu S.-G. (2016) Morphology of Nyctotheroides hubeiensis Li et al. 1998 from frog hosts with molecular phylogenetic study of clevelandellid ciliates (Armophorea, Clevelandellida). J. Eukaryot. Microbiol. 63: 751-759

Li M., Li C., Grim J. N., Ponce-Gordo F., Wang G., Zou H., Li W., Wu S. (2017) Supplemental description of Nyctotheroides pyriformis n. comb. (= Macrocytopharynxa pyriformis (Nie, 1932) $\mathrm{Li}$ et al. 2002) from frog hosts with consideration of the validity of the genus Macrocytopharynxa (Armophorea, Clevelandellida). Eur. J. Protistol. 58: 152-163

Lynn D. H. (2004) Morphology or molecules: How do we identify the major lineages of ciliates (Phylum Ciliophora)? Eur. J. Protistol. 39: 356-364

Lynn D. H. (2008) The Ciliated Protozoa. Characterization, Classification and Guide to the Literature. $3^{\text {rd }}$ ed. Springer, Dordrecht

Lynn D. H., Wright A.-D. G. (2013) Biodiversity and molecular phylogeny of Australian Clevelandella species (class Armophorea, order Clevelandellida, family Clevelandellidae), intestinal endosymbiotic ciliates in the wood-feeding roach Panesthia cribrata Saussure, 1864. J. Eukaryot. Microbiol. 60: 335-341

Martín-González A., Serrano S., Fernández-Galiano D. (1987) Cortical morphogenesis and conjugation process in Caenomorpha medusula (Ciliophora, Heterotrichida). Eur. J. Protistol. 23: 111-121

Nicholls K. H., Lynn D. H. (1984) Lepidotrachelophyllum fornicis, n. g., n. sp., a ciliate with an external layer of organic scales (Ciliophora, Litostomatea, Haptoria). J. Protozool. 31: 413-419

Omar A., Zhang Q., Zou S., Gong J. (2017) Morphology and phylogeny of the soil ciliate Metopus yantaiensis n. sp. (Ciliophora, Metopida), with identification of the intracellular bacteria. J. Eukaryot. Microbiol. (in press) doi:10.1111/jeu.12411

Paiva T. da S., do Nascimento Borges B., Silva-Neto I. D. (2013) Phylogenetic study of class Armophorea (Alveolata, Ciliophora) based on 18S-rDNA data. Genet. Mol. Biol. 36: 571-585

Perty M. (1849) Mikroskopische Organismen der Alpen und der italienischen Schweiz. Mitt. Naturf. Ges. Bern 1849: 153-176

Poche F. (1913) Das System der Protozoa. Arch. Protistenkd. 30: 125-321

Puytorac P. de (1994) Phylum Ciliophora Doflein, 1901. In: Traité de zoologie, infusoires ciliés, Vol. 2, (Ed. P. de Puytorac). Masson, Paris, 1-15

Puytorac P. de, Grain, J. (1976). Ultrastructure du cortex buccal et évolution chez les ciliés. Protistologica 12: 49-67

Saccà A. (2012) The role of eukaryotes in the anaerobic food web of stratified lakes. In: Anoxia: Evidence for Eukaryote Survival and Paleontological Strategies, Cellular Origin, Life in Extreme Habitats and Astrobiology, (Eds. A. Altenbach, J. M. Bernhard, J. Seckbach). Springer, Dordrecht, Heidelberg, London, New York, 403-419

Santos S. M., Guinea A., Fernández-Galiano D. (1986) Étude de l'infraciliature et du processus de bipartition chez Nyctotherus ovalis Leidy, 1850 (Ciliophora, Heterotrichida). Protistologica 22: $351-358$

Small E. B., Lynn D. H. (1985) Phylum Ciliophora Doflein, 1901. In: An Illustrated Guide to the Protozoa, (Eds. J. J. Lee, S. H. Hutner, E. C. Bovee). Society of Protozoologists, Allen Press, Lawrence, Kansas, 393-575

Tirjaková E., Krajčovičová K., Illyová M., Vd’ačný P. (2016) Interaction of ciliate communities with cyanobacterial water bloom in a shallow, hypertrophic reservoir. Acta Protozool. 55: 173188

Vd'ačný P., Foissner W. (2012) Monograph of the dileptids (Protista, Ciliophora, Rhynchostomatia). Denisia 31: 1-529 
Vd’ačný P., Foissner W. (2017) A huge diversity of metopids (Ciliophora, Armophorea) in soil from the Murray River floodplain, Australia. I. Description of five new species and redescription of Metopus setosus Kahl, 1927. Eur. J. Protistol. 57: 35-76

Vd’ačný P., Orsi W., Foissner W. 2010. Molecular and morphological evidence for a sister group relationship of the classes Armophorea and Litostomatea (Ciliophora, Intramacronucleata,
Lamellicorticata infraphyl. nov.), with an account on basal haptorid litostomateans. Eur. J. Protistol. 46: 298-309

Received on $3^{\text {rd }}$ April, 2017; revised on $19^{\text {th }}$ May, 2017; accepted on $26^{\text {th }}$ May, 2017 